\title{
BASIC CONCEPTS AND THEORIES IN INTERNATIONAL PEACEKEEPING: AN ANALYTIC REVIEW
}

\author{
Isiaka Alani Badmus ${ }^{1}$ \\ Bert Jenkins²
}

\section{Introduction}

Peacekeeping has developed over the years as one of the most cogent features of the United Nations (UN), the second universal organisation in the history of international institutions. The system of Collective Security accounted for in the organisation's Charter was for a long period of time underutilised. This is consequent on the ideological bipolarity and East-West dichotomisation of the international system. The Cold War between the then super powers - the US and the defunct USSR incapacitated and nearly crippled the UN ability to resolve armed conflicts on an enduring basis. Furthermore, over politicisation of issues at the UN (particularly by the five veto-wielding powers of the UN Security Council [UNSC]) - the US, the United Kingdom (UK), France, China and the former USSR, now represented by Russia) produced many resolutions full of overstatement rhetoric, peacekeeping (despite the fact that they are not reflected in the theoretical substructure of the UN Charter) becomes an important instrument to maintain international peace and security (Skiemann I998: vii; Weiss et al. 1997). Despite the remarkable achievements of the UN peacekeepers, in the last seven decades of the UN, a world without war still remains elusive. The exponential increase in the number of peacekeeping operations since I988 attests the enhanced expectations of the UN in the post-Cold War international system.

The UN, the sole universal platform for international cooperation and

I PhD, Associate Professor in Peace Studies, Afe Babalola University, Ado Ekiti, Nigeria. E-mail: isiaka. badmusi@gmail.com

2 PhD, Senior Lecturer, School of Humanities, University of New England, Australia. E-mail: bjenkins@ une.edu.au 
management, is today gradually emerging from the stresses and rubbles of the Cold War years. One of the most glaring characteristics and challenges of the post-I989 international system is the proliferation of armed conflicts that are threatening the state structures from within its borders (Straus 20I2). The withering away of the Cold War politics and increase in ethno-linguistic and sectarian conflicts that are champion by various social and resistant movements, armed rebel groups, and non-statutory security forces challenging the state monopoly of instruments of violence have brought a new era of international relations and with it, a new beginning in the work of the UN forces (Boutros-Ghali I993). It is instructive, however, that the dynamics of international relations starting from I990 has also created a new environment where the tasks of conflict management have become more complex, diverse, and urgent. The shift from interstate conflicts to local ones has raised the expectations about a more significant, dynamics, and innovative conflict management roles for the UN in this era of international cooperation.

Deriving from the foregoing analysis this paper reviews some key literature in the field of peacekeeping. The essay provides a detailed account on intellectual efforts in conceptualising peacekeeping and the three major approaches to think conceptually about peacekeeping, the problems brought about by these approaches as well as that of peacekeeping taxonomy/classification in the intellectual history of peacekeeping. We explore the linkages between globalisation and global politics as well as their impacts on the nature and practice of peacekeeping. We then situate the study and analyses of peacekeeping in the broader context of international politics and international relations theory. We examine four major theories (Liberal Peace thesis, Cosmopolitanism, Global Culture, and Critical theory) in order to explain how they help or hinder our understanding of peacekeeping. Without doubt, peacekeeping literatures are too vast and diverse to comprehensively cover; nevertheless, we review some early key studies on the subject of enquiry with the objective that it will put the current literature in context.

\section{Peacekeeping, Globalisation and Global Politics: Definitional Housekeeping and Conceptual Discourse}

Peacekeeping is a term use in different ways by different people scholars, analysts, and peacekeeping practitioners - based on their different theoretical orientations/traditions (Kondoch 2007). Simply put, peacekeeping is a mechanism adopted by the UN for conflict management. It is always involve an interposition of forces between the warring parties by creating a 
buffer zone. Peacekeeping is an operation that is essentially undertaking to maintain a ceasefire. In its traditional form, it (peacekeeping) involves the deployment of military personnel to conflict theatres with the responsibilities for supervising the buffer zones and monitoring ceasefire agreements. According to the UN, peacekeeping is "...an operation involving military personnel, but without enforcement powers, undertaken by the United Nations to help maintain or restore international peace and security in areas of conflict. These operations are voluntary and are based on consent and cooperation. While they involve the use of military personnel, they achieve their objectives not by force of arms, thus contrasting them with the 'enforcement action' of the United Nations under Article 42" (United Nations I990: 4). The peacekeeping approach represents a different formulation of the UN role in peace and security from those envisaged in Chapters VI and VII of the UN Charter. It has added a new dimension to the traditional diplomatic instruments of negotiation, conciliation, and mediation. Aware that the introduction of peacekeepers by the UN into conflict zones is to stabilise an exploding military situation until the basis of a more durable settlement could be established. This process provides the warring parties with a buffer zone, behind which they will negotiate and work towards a pacific settlement of their conflict (Bassey I993: I88).

Peacekeeping is not an end in itself in the conflict resolution continuum. Rather, it is a means in which its success depends on other conflict resolutions efforts at the political level such as good offices, arbitration, and negotiation, among others. Therefore, peacekeeping needs to be deployed to support functional political processes (Bellamy, Williams and Griffin 20I0). Since the development of this approach to conflict management and resolution, peacekeeping operations had been carried out in such places as Lebanon, Somalia, Cyprus, Sierra Leone, the Central African Republic (CAR) to mention but a few.

Having provided a brief explanation on peacekeeping, we then examine the impacts of globalisation and global politics on the nature and practice of peacekeeping. The practice of peacekeeping is currently being influenced by the dynamic nature of global politics. Globalisation is a contested concept and is subject to different theoretical interpretations. Since this paper is not concern with developing a theoretical framework for globalisation, it is suffice to provide a brief explanation on the concept. From the liberal theoretical perspective, globalisation is an increasing integration of the activities of human societies globally. It is both vertical and horizontal integration processes that involve growing number and array of transnational transaction activities, in goods and services. This integration processes also involve international 
capital flows, in human migration. All these are made possible by/through a quick and extensive diffusion of technology (Bello 2003).

The processes of globalisation have transformed world politics from a Westphalian order, with the state as its basic unit of analysis, to a post-Westphalian order exemplified by transnational activity, global communications, and a diverse array of politically important actors (Bellamy, Williams and Griffin 2004: II). This transformation has raised intense debate among scholars as to what exactly the roles of peacekeepers should be in this highly dynamic international context. The struggle between those scholars that see peacekeeping activities in global politics through the Westphalian prismatic lens and the adherents of a more grandiose post-Westphalian conception centres on the whole issue of liberal democratic peace ${ }^{3}$. The opposing schools unanimously accept the fact that liberalism promotes peaceful coexistence but differ on exactly what the liberal democratic thesis is all about. The Westphalian conception of peacekeeping is based on a more narrow understanding of democratic peace since it argues that the peacekeeping domain should be confined to peaceful resolution of international conflicts (interstate conflicts) and in facilitating peaceful relations between states. Indeed, Bellamy, Williams and Griffin (2004: 2) offer a critique of this position because from the Westphalian point of view, according to them, it means that: "ideological persuasion and political organisation of the societies within states should not concern peacekeepers, so long as states subscribe to the Westphalian norms of sovereign autonomy and non-intervention." Therefore, the Westphalian perspective contends that conflict and disorder within a state (internal conflicts) and the ensuing complex humanitarian emergencies/catastrophes are beyond the jurisdiction of peacekeepers.

Contra the state-centric Westphalian paradigm are those scholars that see peacekeepers' roles in world politics in a larger context and have a deeper understanding of liberal democratic peace (see Paris 2002). This perspective suggests that: "liberal relations between states require liberal-democratic societies within states, because it is assumed that the way that a particular state conducts its international affairs is inextricably connected to the nature of its democratic society" (Bellamy, Williams and Griffin 2004: 2). This (post-Westphalian) position suggests there is a symbiotic nexus between the internal affairs and international relations of a state, and that mis-governance and anarchy within a particular state has the tendency to disrupt international security (see Hoffmann I995: I67). Consequently, the post-Westphalian conception

3 Liberal Democratic Peace Thesis is discussed extensively under the section on theoretical approaches to the study of peacekeeping. See also Chan (I997); Richmond (2007) and Russet and Harvey (2000). 
of peacekeeping transcends the classical peacekeeping model to include an all-encompassing task of ensuring stability at the domestic level of the individual state, which is achievable through exporting liberal democratic values to societies, and states that are experiencing or those that have experienced political instability and anarchy.

The contention between these opposing perspectives mirrors the longstanding debate between on the one hand the ardent supporters of the UN Charter that favour the classical principles of international norms and rules of inter-state relations which put a premium on the sovereign equality of states and are based on belief in primacy of the principle of non-intervention in a state's internal affairs. On the other hand there are those scholars that are in support of international humanitarian law (IHL) arguing that state security (in the realist sense) or the security of individuals within a state should be of utmost importance to the community of civilised states. The idea of non-intervention in internal conflict situations (the Westphalian conception of peacekeeping in global politics) has found support among developing countries, while the advanced states in the West have championed the thesis of development from the basis of human rights norms and IHL (Duke I994). This stand by the West has made state sovereignty not so absolute, as matters of human rights are now issues of international concern, meaning they apply to situations both within and between states. Based on this development and understanding, governments can no longer use state sovereignty as an excuse to escape sanctions when they are the perpetrators of human rights abuses on their citizens or when they fail in their duties relating to the protection of populations, especially in conflict situations (Ignatieff 2002). Doubtless, this position authorises and legitimizes peacekeepers' intervention roles within a state's internal affairs, thereby supporting the post-Westphalian conception of peacekeeping. Furthermore, we argue that the Westphalian peacekeeping perspective seems not to capture the recent trends in peace operations where the UN, regional arrangements, and alliances of states, for example, 'coalitions of the willing states', intervene in internal conflict situations to bring peace and security within states and to regions. There is evidence of this perspective from recent UN peacekeeping operations in Africa and Africa's regional and sub-regional organisations such as the African Union's (AU) peace support operation in Burundi (the African Mission in Burundi or AMIB) and the African Union Mission in Somalia (AMISOM), and the Economic Community of West African States's (ECOWAS) peacekeeping and peace enforcement operations in West Africa in the I990s and 2000 s have demonstrated. Apparently, we assert that what is missing in the pro-Westphalian scholars' argument is that it is just that the UN or any intervention force has to contend with the complexities associated with issues of sovereignty and the use of armed inter- 
vention as per the UN Charter, international law and the requiring of consent from governments of nations in which interventions take place.

In analysing the debate and the impacts of the lack of consensus among scholars, Bellamy and his colleagues (2004: 3) conclude thus:

To date, this struggle has not been conclusively resolved. Indeed, we argue that this ongoing tension lies at the heart of many of the theoretical and practical difficulties that today's peacekeepers are experiencing. However, the processes of contemporary globalisation are shifting the debate in favour of post-Westphalian conceptions of peacekeeping. The processes are not only increasingly blurring the empirical distinctions between domestic and international politics; they are also encouraging a greater, though still limited, concern with human wrongs wherever they may occur.

In other words, globalisation is not only changing the environment in which peacekeepers operate, but it is basically affecting the self-images they hold about their own roles in global politics.

Three major approaches to think conceptually about peacekeeping are discernible in the literature. These include: (I) The Case Study Approach, (2) The approach based on the Features, Functions, and Types of peacekeeping, and (3) The Third Party Mediation Approach. The central thesis of the case study approach, favoured by such scholars as Durch (ed.) (I993), (I997); James (I996);; Skogmo (I989); Weiss (I995); Wolfgang and Martin (eds) (I998) and recently influenced by the writings of Adebajo (2002); Chesterman (2002); Chopra (2002); Dallaire (2004); Ginnifer (2002); Goldstone (2004); Howard (2002); Ian and Mayer-Rieckh (2005); Rogie (2003); Suhrke (2001); Olonisakin (2008), Badmus (20I5), (20I7) is that because of its ad hoc nature in response to each problem, peacekeeping is best approached conceptually on a case-by-case basis. Therefore, the description and analysis of peace operations becomes the basic objectives and tasks associated with this approach. The case study approach has the merit of differentiating between operations and it is also beneficial in helping to overcome the bias stemming from the penchant towards regarding all the pre-I989 peacekeeping activities as being of a Westphalian type, and vice versa. Furthermore, this approach offers comprehensive explanation of 'lessons learned' for correcting the mistakes of the ongoing peace missions or such lessons learned can be the basis for planning and conducting future peace operations (Johnstone 2005). Despite these merits, the case study approach fails to offer a comprehensive analysis and understanding of the changing roles of peacekeeping in global politics. This approach is also criticised as being too restrained to specific cases in its analysis, 
thus, making its focus narrow. In addition, Diehl, Druckman and Wall (I998: 34) reject this approach as misleading, for they see it as an approach that is based on the uniqueness of peacekeeping missions; that it is not helpful in building a theory of peacekeeping; and it also fails to provide much guidance in policymaking by only supporting efforts to find lessons learned from whatever happens to be the most recent or important operation. Diehl and his colleagues argued further that attempts by some scholars to generalise and even use multiple case comparisons is equally erroneous because treating all missions as the same under the general term of 'peacekeeping' has the tendency to compound the problem of classification further because according to them there are, in contemporary time, many types of peace operations and as such it becomes difficult to assess whether generalisations about one type are applicable to others.

There is also an attempt in the literature to classify peacekeeping based on its general features, functions and roles as 'indexes' of classification as a way of overcoming these conceptual misunderstandings. Using what we refer to as the 'Taxonomy Approach', the erstwhile UN Secretary General, Boutros Boutros-Ghali, in his Agenda for Peace (I992: 20) defines peacekeeping as the "deployment of a United Nations presence in the field, hitherto with the consent of all the parties concerned, normally involving United Nations military and/or police personnel and frequently civilians as well. Peacekeeping is a technique that expands the possibilities for both the prevention of conflict and the making of peace." The former UN official offered a new typology for the UN's role in conflict management in the post-Cold War era, which can be summarised as follows:

- Preventive Diplomacy: aimed at taking action to prevent conflicts from arising in both

violent and non-violent situations.

- Peacemaking: aimed at bringing hostile parties together by peaceful means as determined in Chapter VI of the UN Charter.

- Peacekeeping: the deployment of a UN presence in the field, with the consent of the

parties, to stop conflicts and preserve peace once established.

- Peacebuilding: post-conflict action aimed at ensuring that violence does not reoccur and to identify and support structures that will strengthen the peace (see O'Neill and Rees 2005: 6).

Assessed against the background of the foregoing analysis, 
Boutros-Ghali's typology is beneficial because it points to the fact that conflict prevention and peacekeeping by themselves are not enough in making efforts towards achieving sustainable peace, which are functions of the twin forces of peacemaking and peacebuilding processes. The Brahimi Report (2000, para. Io) fully supports Boutros-Ghali's position that UN peace operations can involve conflict prevention and peacemaking, peacekeeping and peacebuilding activities. Transcending the principles ('holy trinity') of the classical peacekeeping model, Boutros-Ghali made a compelling case for the relaxation of the consent requirement in order to facilitate UN quick deployment of peacekeepers in volatile situations where the belligerents' consents proved difficult to secure (see Neethling 2009: 2-3). Despite the fact that many peacekeeping scholars and practitioners supported Boutros- Ghali's categorisation (Diehl, Reifschneider and Hensel 1996; Goulding 1993; White 1997), there is general cynicism towards his attempt to expand on this definition and typology. Boutros-Ghali's conceptual framework has, at best, been hindered by uncertainty and unpredictability. Rejecting Boutros-Ghali's categorisation, Bellamy, Williams and Griffin (2004: 13) asked rhetorically: "what, for instance, are we to make of operations that carry the label of 'peacekeeping' but do not enjoy the consistent consent of all the parties or do not exclusively employ UN personnel?"

Durch (I997: 8), in his study of Peacekeeping and Lessons of the 1990s, identified four types of peace operations: traditional peacekeeping, multidimensional peace operations, peace enforcement, and humanitarian intervention. Such scholars as Demurenko and Nikitin (1997), Diehl, Druckman and Wall (I998) offer a more detailed typology. In line with this taxonomy, Diehl, Druckman and Wall (I998: 39-40) classified peacekeeping operations into I2 categories ranging from traditional peacekeeping to sanctions enforcement through pacification, while Demurenko and Nikitin (I997) presented seven types of peacekeeping. Bellamy, Williams and Griffin (2004) listed five types of peacekeeping: traditional, managing transition, wider peacekeeping, peace enforcement, and peace support operations. Segal (I995) based his historical classification on chronology. His typology is more concerned with the political conditions that warrant peace mission authorisation and is not particular as to the features of the peace operations themselves. However, in practical terms, conventional wisdom attests to the fact that they are interrelated and are, at best, inseparable. However, Diehl, Druckman and Wall (I998: 35) raised the lacuna in criticising Segal's typology because, according to these authors, this (Segal's) typology may be helpful in describing the UN's peacekeeping genesis and its development, but it fails to give theoretical guidelines for comprehending different peace mission types, how peacekeeping successes and 
failures could be measured, and what type of training is most appropriate amongst other issues.

Since the end of the Cold War, some scholars have classified various peacekeeping missions under convenient but misleading labels. In this connection, Goulding (1993) argues that there are 'three generations' of peacekeeping, while Thakur (2005) suggested 'six generations' of peacekeeping. Thakur and Schnabel (200I) also listed six 'cascading generations' of peace operations: traditional, non-UN, expanded, peace enforcement, peace restoration by partnership, and multinational peace restoration/UN state-creation. Other scholars contend that only two types of peacekeeping exist, the Westphalian, traditional peacekeeping of the Cold War years and the 'new peacekeeping' (Ratner 1995) or 'second-generation' peace missions (Mackinlay and Chopra I992). Nishihara even went further and based his categorisation on the peacekeepers themselves. In his study titled, Trilateral Country Roles: Challenges and Opportunities (I993), Nishihara identified three different types of peacekeepers: (I) full-fledged peacekeepers, (2) self-restrained peacekeepers, and (3) peace enforcers. In this context, O'Neill and Rees (2005: 7) are of the opinion based on Nishihara's definition that Irish soldiers (troops) were at different times in category (I) in Cyprus, category (2) in Somalia, and in category (3) in their involvement in $\mathrm{ONUC}^{4}$, provided it is accepted as a case of peace enforcement. It is on this basis that O'Neill and Rees (2005) warned that such categorisation has to be treated with great care.

Without any doubt, identifying the key features and roles of different types of peacekeeping is very interesting and offers a useful approach in comprehending peacekeeping, but these are not without shortcomings. First, the existence of different categories of peacekeeping is indisputable, but classification into different 'generations' is misleading and, at best, an anachronism since such efforts are bound to create inconsistencies or even compound the existing definitional ambiguities and conceptual misunderstandings. Johnstone (2005: 7) offers a critique of this approach in saying: "While these taxonomies give a sense of the broad range of operations that are not always well-described as peacekeeping, the more numerous the categories and the more subtle the distinction between them, the less useful they are as analytical tools."

Furthermore, the approach seems lacking in flexibility because it conceals the important fact that peacekeeping operations can perform numerous functions at the same time and can even oscillate between different types (Diehl, Druckman and Wall 1998: 38; Diehl 2008: I4. see also Diehl and

4 ONUC is the French acronym for the United Nations Operation in the Congo. 
Druckman, 20I0). Further criticism of the taxonomy approach is that it fails to provide comprehensive explanations of the changing nature of international politics and how this has metamorphosed peacekeeping and, by extension, the role of peacekeepers. Finally, in his research on the taxonomies of international peacekeeping, Wilde (200I) finds that the 'generations' terminology is not beneficial to the understanding of peacekeeping and is normatively problematic. Wilde argued that the taxonomy approach erroneously means that there has been a positive development through successive generations of growing complexity, and it falsely portends improvement. That is, it deceptively promotes the idea that the successive generations of peacekeeping are in some way better than their preceding types of peacekeeping missions. These reasons explain why this approach of classifying peacekeeping based on its features, functions and roles has been rejected and regarded as self-referential.

The third approach in the peacekeeping literature considers peacekeeping as a form of third-party mediation (Fetherston I994a\&b, 2000; Fetherston, Ramsbotham and Woodhouse 1994). Fetherston proposes a theory of peacekeeping that is rooted in the concept of peaceful third-party intervention. Developing this line of argument, she contends that for the UN to successfully resolve the post-Cold War conflicts, the practice of peacekeeping needs to be based on a theoretical framework that considers both the means and ends as essential. Fetherston rightly assessed that in the contemporary international system where the UN is engaging in larger and more complex involvement in armed conflicts there is a compelling need for a better developed and researched understanding of success (Fetherston i994a: 42). Contingency models form the basis of Fetherston's framework and she contends further that presently what is expected of peacekeepers (that is, mediation, consultation, facilitation, negotiation among others) and the type of (military) training they undergo are diametrically opposed. Fetherston recommends her conceptual framework as the best approach to the enhanced performance of peacekeepers. Similar in tone to, and developing Fetherston's stance further, Ryan (2000) used different stages of conflict to make a case for the appropriate time for peacekeeping intervention. Despite its merits, this approach fails to consider the essentially political and unpredictable character of situations and spaces in which peacekeeping operations are deployed.

The logical conclusion from the foregoing discussions is that despite the existing multiple frameworks for addressing the conceptual problems of peacekeeping in the literature, these approaches overlooked the imperative of the structures and processes of world politics, their impacts and how these have conditioned the roles of peacekeepers in it. Furthermore, dissipating 
too much energy and time on the classification of peacekeeping missions has made scholars to play down the embedded ad hoc and political character of such missions, which obscures discords about their real purposes.

\section{A Theoretical Approach and Framework}

While there are increasing numbers of articles and scholarly monographs contributing to peacekeeping literature following the end of the Cold War, attempts at theorising peace operations are relatively recent (Barnett I995; Bellamy, Williams and Griffin 2010; James I990; Pugh 2003)5. Johnstone $(2005)$ attributed the increases in peacekeeping literature in the postI989 period to three major factors. The first is the increase in the number of peace operations undertaken by both the UN and regional organisations since I999. Second, the release of the Brahimi Report in 2000 and third, the September 200I terrorist attacks on the US that is regarded as a critical point at which it was necessary to think anew about international security and new forms of threats to the international system. The September 200I terrorist attacks changed the way security is analysed. Indeed, Johnstone (2005) argued further that the September 200I event brings forth a trend that started some years back in analysing peacekeeping in the wider context of international politics and international relations theory. Thus, the need to broaden the study of peace operations engages scholarly writings (Paris 2000; Pugh 2003). For his part, Paris (2000) calls for thinking more theoretically about peace operations. He suggests that there is an urgent need to study peace operation in order to transcend practical operational issues and instead examine peace operations as a window that leads into an arena where it is possible to focus on larger phenomena associated with international politics.

Moreover, Bellamy, Williams and Griffin (2004) argued that despite a plethora of scholarly writings on peace operations that have looked at the strengths, weaknesses as well as experiences of peace operations, there is little or no attempt made to look critically at the influence of global politics and the role of peacekeeping within it. These scholars try to fill this gap by dichotomising views on the practice and theory of peacekeeping (or peacekeeping's role) into Westphalian and post-Westphalian standpoints, which I have explained earlier. Equally, Bellamy (2004), Bellamy and Williams (2004) and Pugh (2004), in a special edition of an academic journal, 'International Peacekeeping', on Peace Operations and Global Order, edited by Alex, J. Bel-

5 According to Bellamy, Williams and Griffin (20I0), exceptions to this trend were the earlier standard works of Fetherston (I994a) and Rikhye (I984). 
lamy and Paul, D. Williams have devised an approach that divided the field into 'problem-solving' and 'critical' approaches as a way of thinking anew about peacekeeping. While these theoretical approaches are important, what distinguishes the 'problem-solving' theory from the other is that it takes the contemporary world as it is and tries to find solutions to the problems that emanate from them. In contrast, critical theory questions the prevailing international order in order to unravel and expose the interests it actually serves and protects, with the objective of transforming the order in such a way that it safeguards the interests of those who are disadvantaged (Cox I98I; Booth 2007). According to Pugh (2004), a significant proportion of the peacekeeping literature leans towards the 'problem-solving' theoretical framework, which, in his opinion, is detrimental since it limits the ability of students of peacekeeping to think ingeniously about the role peace operations play in the greater scheme of things. He therefore suggested a different framework to the study of peacekeeping, that is, a theoretical approach, which questions the accepted wisdom of peacekeeping and the global order it serves (Johnstone 2005: 2).

The need to think theoretically about peace operation is very important because neglecting theory from peacekeeping studies will, according to Bellamy, Williams and Griffin (2010: I9) limit our ability to understand the whole gamut of issues in peace operations ranging from the gendered effects of some peacekeeping practices to the ideational basis of peace operations. This is because, as these scholars have explained, situating the study of peacekeeping within a theoretical framework assists us to understand the complex social interactions involved in peacekeeping, and this in turn influences what we should study, how we study these phenomena and subsequently also the conclusions we reach. Therefore, we now turn to examine four of the main theoretical approaches that are discernible in the peacekeeping literature, which offer possible frameworks for the analysis and interpretation of peacekeeping research. Our examination will focus on three major areas: (I) the basic tenets of each theory, (2) their shortcomings and (3) major arguments of their critics and the alternative ways to think about them.

\section{Liberal Peace Theory}

Despite the dominance of realism, the liberal peace paradigm has occupied a very important place in international relations theoretical discourses

6 Some of the logic of liberal peace has been discussed in the preceding section especially on the post-Westphalian conception of peacekeeping. 
(Dunne 20II). Liberalism, as a theoretical framework, differs markedly from realism that projects the international system as potentially anarchical (Morgenthau I973; Keohane 1986; Vasque I983; Waltz I979; Wayman and Diehl I994 to mention but a few). Despite the fact that different realist scholars, based on their diverse orientations of political realism/power politics paradigm, make different assumptions, they tend to unite on three general assumptions (Holmberg I998: I2). First, realists emphasise the centrality of the state, in that state is the principal actor in the international system, and anarchical situation prevails in the absence of a world government. Second, in the context of world politics, state is seen as a rational actor that always striving to maximise their expected gains and utility. States are assumed, as Holmberg (I998: I3) argued, "to carefully rank different alternatives and to calculate the costs and gains of each action." Third, the centrality of power is an important element of the realist theoretical framework. The assumption here is that, in the international system, states seek power to expand or maintain their position. Thus, the objective of the state in international system is maximisation of power and the means is also power. In his book, Politics Among Nations (I949: 210), Morgenthau aptly captures the essence of realism thus: "all nations actively engaged in the struggle for power must actually aim not at a balance - that is, equality - of power, but at a superiority of power in their own behalf."

In contrast, liberalism seeks to project the importance of freedom, justice and order into international relations. In the specific case of peace operations, liberal peace theory is indubitably the most dominant. With respect to peacekeeping operations, proponents of liberal peace theory maintain that stable peace could be achieved when the theory and practice of peacekeeping are informed by the liberal peace thesis (Paris 2004). This implies that conflicts can be reduced through the spread of liberalism across countries of the world. The implicit assumption of the liberal peace theory is that democratic states do not wage war on other liberal democracies. This observation does not imply that liberal states do not go to war at all or that they are less warlike in their inter-state relations with illiberal states. The suggestion is that liberal states should choose not to wage war and that because they lean towards liberalism, they are at least more likely to be peaceful when compared to 'less than liberal' states and this reason explains why democratic states are the least likely to fail and collapse into anarchy. This claim is of course contestable, as perhaps obvious, liberal states do wage war on states they deem to be 'less than liberal', which in itself is an aggressive act or expression of non peaceful behaviour. Such actions often take place by extending the argument that these states have 'failed' and need democratising or fixing to become ideal liberal 
democratic state systems.

As Bellamy, Williams and Griffin (20I0: 23) contend, scholars following liberal peace theoretical traditions offer two explanatory justifications for this scenario. First, liberal democratic states have well-established domestic political institutions. These include an independent judiciary, a legislature together with an effective rule of law that put checks on the powers of their leaders to wage wars irrationally with rebel groups within their state or with other nation states. Also, many of the international organisations to which these states belong are guided by democratic norms, values and principles that equally renounce war as an instrument for achieving foreign policy objectives and/or the basis of maintaining good international relations (Owen 1994). Therefore, liberal states are guided by democratic norms that guarantee human emancipation and value pacific settlement of political disputes. Second, at the domestic level of an individual state, the tendency for war between and among democratic states is reduced because of the democratic norms and values that direct these states as they 'recognise one another's legitimacy.'

Linking liberal peace theory to peace operations, the mounting of peace missions is assumed to serve the interests of liberal democracies by promoting the basic tenets of liberal peace. Strengthening this argument further, Bellamy, Williams and Griffin (2010: 24) stated:

This is most apparent in those peace operations that seek to build peace within states-which are increasingly becoming the norm...These operations try to build stable peace by enabling the creation of democratic societies and liberal free market economies. They are often supported in this endeavour by Western NGOs (Italics in original).

From a liberal perspective, liberal peace intervention is necessary and justified based on the fact that a society that has descended into conflicts and armed violence with negative consequences on its civilian populations can no longer claim sovereignty and non-intervention (Jabri 20I0: 42)

Despite its importance, liberal peace theory has been subjected to criticisms especially from the Third World regions and China since it promotes the post-Westphalian conception of international relations and peacekeeping, which are influenced by neo-liberal political ideals for a globalising world economy (Harvey 2007. see also Bellamy 2009). Critics of this theory argue that peace operations should be deployed to resolve inter-state conflicts but see attempts made to extend the role of peacekeepers to deal with internal conflict situations as being nothing but a calculated attempt/effort by the West to impose neo-liberal ideologies and agendas on states that have 
espoused other ideologies that are contrary to their own. The argument here is that UN peace operations, and the installation of 'peace' by military interventions of either individual states or a coalition of willing states, especially those of the major Western states, are designed to impose both liberal and neo-liberal agendas on the unruly parts of the world (Richmond 2007; Pugh 2004). In the wider context of peacebuilding operations, UN peacebuilding operations and the role of international financial institutions, the World Bank and International Monetary Fund (IMF) (in terms of their qualified relationships with the erstwhile adversaries in troubled zones) in conflict zones are contestable. This is because UN peacebuilding operations are seen as nothing but a problem-solving approach aimed at stabilising the prevailing order first and then later attempting to reorganise a state in which an intervention has occurred, and doing so according to the liberal peace agenda (Richmond 2007; Richmond 2010: 24-25). Richmond (2007: I5O-I5I) argues that critics believe that the importation of the liberal democratic model to communities in troubled zones through military (peacekeeping) interventions and post conflict rebuilding efforts of the international financial institutions are just to provide the communities in conflict zones a 'breathing space'. Through this breathing space, international help, it is argued, will make it possible for the construction of a new liberal peace by getting rid of nationalism and ethno-nationalism and as a consequence liberal democracy will then be successful. Therefore, according to the critics of liberal peace, as Richmond (2007: I50) contends, "This breathing space effectively means an illiberal peacebuilding interval where governance is controlled by external actors until they deem it to be sustainably constituted, whereupon governance is returned to local institutions and populations." International actors therefore own the peacebuilding process instead of local populations. The arguments against the current neo-liberal application of liberal peace theory have made its opponents support the idea that international peace and security can only be achieved and maintained when the economics and governance aspects of state sovereignty are respected. The problem with this view is that it may take us back to the absolute sovereignty demands of yesteryear in which the peacekeeping role is limited to interventions in interstate conflicts. Consequently, those opposed to the current applications of liberal peace theory, as it is being practiced today, have somewhat limited the ability of the UN to deploy a peace mission to impose the neo-liberal version of the current liberal peace agenda under three conditions or situations. These include the complexities associated with the following scenarios: First, when the UN is invited by the conflicting parties themselves (or their representatives) to help install democratic governments as the cases of Cambodia (see Richmond and Franks 20II) and Burundi illustrate. Second, when the UN deploys peacekeepers to defend democracy 
by reinstating ousted democratic governments by illegitimate means as happened in Haiti and Sierra Leone, and thirdly, when the UN and other regional arrangements have made efforts to create liberal peace in the context of intervening in the affairs of collapsed or so-called failed states, as was the case in Bosnia, and possibly Iraq and perhaps Somalia as well. Further criticism of liberal peace theory points to the core fact as argued some time ago by Mearsheimer (I994), that the liberal peace thesis is contested in that wars between liberal states are not an exception and this questions the very basis and validity of the data on which the theory and its empirical assumptions are based. This critique is still valid today.

\section{Cosmopolitanism and Peace Operations}

The cosmopolitan theoretical approach to peace operations gains insights from cosmopolitan political theory. According to scholars (Björkdahl 2005; Hannerz 2005; Nussbaum I996), the renewed interest in cosmopolitanism 7 , especially in the late part of last century, is a result of globalisation, nationalism, identity politics, migration and multiculturalism. Björkdahl (2005: 215) noted that cosmopolitanism is seen as a political alternative to nationalism and cosmopolitan values laid emphasis on political inclusivity, accountability and strongly opposes identity politics and other ideologies that promote political exclusivity (see also Held I995). Within the context of the international system, cosmopolitanism is considered as an approach that can tackle the new types of threats to international security such as international terrorism and organised transnational crimes that cannot be solved by the state through individual effort but they demand a synergy of efforts of a network of states (Kaldor I999). Arguing along the same lines and drawing on the findings of Kaldor (I999), Björkdahl (2005: 215-2I6) maintained that it is the reality of the menace of these global problems and efforts to combat them through concerted efforts that states have established a form of cooperative alliance that can be seen as a cosmopolitan mode and also serve as a platform for global responsibility to promote and uphold humanist principles and norms associated with cosmopolitanism. Indeed, the practices of both peacekeeping and peace enforcement action are cited as an exemplar of a cosmopolitan politics capable of safeguarding human rights and protecting

\footnotetext{
7 Cosmopolitanism itself is a concept that has been subjected to different interpretations by scholars. It has been differently interpreted as cosmopolitics, global democracy, world citizenship and sometime as a vision of world government (Archibugi and Held (eds) I995; Cheah and Robbins I998; Falk I998).
} 
civilian populations ${ }^{8}$.

The central argument of the cosmopolitan approach is that the promotion and diffusion of cosmopolitan values is considered as a possible contribution to create conditions and circumstances necessary for conflict prevention and resolutions through peaceful means. Therefore, the construction of peace and stability can be achieved through the spread of cosmopolitan values and therefore peacekeeping operations require to be conducted in such a way as to promote these values and uphold the commitment to humanist principles and norms. This belief is premised on the basis that conflict prevention norms and principles are believed to have cosmopolitan features. Building on this theoretical framework, Woodhouse and Ramsbotham (2005) made a compelling case for the development of cosmopolitan peace operations that need to be conducted by a standing UN Emergency Peace Service that is strong enough to protect civilians. Woodhouse and Ramsbotham's argument bear some resemblance to Michael Pugh's (200I: 347) understanding of cosmopolitanism, which required the "...spread of norms that secure human rights, democratic freedom and social justice." In a similar vein, Kaldor argued for peace operations to be proactive and serve as an instrument of cosmopolitan law enforcement (I999: 124-126). This scholar's argument is that since the construction of 'legitimate political authority' is central to put an end to the post-Cold War armed conflicts, then, it means that such solutions could be achieved through the enforcement of human rights law and IHL (that is the enforcement of cosmopolitan values) and through this effort civilians will be better protected and also perpetrators of human rights abuses and war mongers arrested and punished (Kaldor 2006).

Assessed against the background of the foregoing analysis, we pose key question: How do cosmopolitan peace operations function in Kaldor's framework? Kaldor draws attention to the fact that such proactive (cosmopoli$\tan$ ) peacekeepers will be professionally competent to perform both soldering and policing tasks, which involve a combination of traditional and new multifunctional peacekeeping tasks. Kaldor argued that proactive peace operations are characterised by impartiality but not neutrality, for it is likely that proactive peacekeepers become a party to the conflict by supporting innocent civilians in order to protect them as part of their mandate (Kaldor I999: 125). Proactive peacekeepers need not rely on securing the consent of all belligerents but rather rely on what is needed, which is the consent of the victims. Thus, this required cosmopolitan peacekeeping forces to use force against parties that threaten civilian populations and seek to disrupt the peace operation and its

8 Scholars such as Kaldor (2003), Taylor (I999) and Zolo (I9997) have variously described it as cosmopolitan law enforcement, proactive cosmopolitanism, and cosmopolitan wars. 
mandated objectives. In this cosmopolitan scenario, armed peacekeepers can enforce peace under certain conditions where the use of force is a means of protecting civilian populations from being harmed.

Despite its merits, the cosmopolitan approach has been criticised in many ways. First, there is the belief that a cosmopolitan rhetoric may be used as a cover by the powerful states to further their geopolitical or natural resource extraction interests. This is a reason for why scholars have to interrogate the interests that such cosmopolitan peace operations serve. This reason may have prompted Björkdahl (2005: 223) to ask: "will cosmopolitanism as a tool for peace and security be used selectively and simply reinforce Western or great power or UN Security Council interests?" Furthermore, diffusing cosmopolitan norms and values through peace operations has been criticised as the spread of 'Western' rather than universal values and that cosmopolitanism is nothing but the spread of power and influence of major western countries in the world with the covert goal of neo-colonial and imperial domination of weaker states from which 'something' is required or where some strategic advantage is desired. Second, cosmopolitanism has been criticised as being an 'illusion' (Himmelfarb I996: 77), or 'abstract universalism' (Barber I996: 30) and that it is based on a simplistic conception of new conflicts by seeing them as involving innocent victims and their tormentors (Bellamy, Williams and Griffin 20I0: 27) and not much more.

\section{Global Culture and Peace Operations}

This theoretical approach is rooted in world polity theory, which is located within the discipline of sociology (Boli and Thomas I999; Thomas et al. I987; McNeely I995). World polity sociologists engage themselves with the understanding of the norms, customs and culture of human societies. Within the tradition of the world polity scholars, there is the need to have a macro-conception of the world as a single society instead of looking at (or studying) the culture of a particular group, society or nation. According to these scholars, as Paris (2003: 442) argued: “... there is a distinct global culture that comprises the formal and informal rules of international social life" (Italics in original). The global culture (also known as the international normative environment) defines the major actors in world politics and their conduct. Therefore, these informal and formal social rules guide the international system, inter-state relations and world politics, as well as having profound impacts/influence on the design and conduct of peacekeeping operations.

Following on from the above analysis, and building on sociology's 
world polity theorists, the global culture approach helps to explain why peace operations embark on some strategies/activities that are well thought-out as appropriate and which de-legitimise others, whether or not such strategies are capable of helping peace missions to accomplish their mandates and achieve peace (Bellamy, Williams and Griffin 20ı0: 26). This implies that peacekeeping agencies design and deploy peace missions to implement policy tools that obey the rules of a particular global culture while those strategies that deviate from these values are ruled out. This reasoning explains why the international trusteeship is disqualified as appropriate strategy for its presumed 'neo-colonial overtones' despite its post-Second World War positive records associated with development. Despite its new insights into why peacekeeping authorising institutions adopt and pursue certain strategies and discard others that are regarded as normatively inappropriate, Paris (2003: 45I) criticised the global culture approach on the grounds that it "constrains the practice of peacekeeping by limiting the range of strategies that peacekeepers can realistically pursue." Therefore, the major weakness of this theoretical framework is that it limits peacekeeping mandating institutions such as the UN and regional arrangements (the African Union [AU] for example) to discard some policy tools, prima facie, simply because they are not conforming with the acceptable norms of international society without first giving such strategies proper consideration to ascertain whether or not they have the possibility to help a peace mission achieve peace.

\section{Critical Theory}

Critical theory takes its point of departure from classical theories (such as liberalism/neoliberalism and realism/neorealism) to the study of international politics. In specific term, it draws on, and gains insights from, the works of Cox (I98I), Horkheimer (I982) and other scholars of the Frankfurt School, and also of critical security studies scholars, especially those associated with Aberystwyth (Booth 2007; Wyn Jones I999). Cox (I98I) deconstructs the nature of global order and transformation based on his adaptation of the Frankfurt School's sociological critiques and submits that the orthodox theories are ideologies designed purposely to deal with instabilities within a world order that is itself dysfunctional (Pugh 2004: 40). Therefore, the mainstream theories are designed to serve the interests of dominant (capitalist) states at the expense of world peripheries and fail to question this prevailing dysfunctional world order (Cox I98I). Based on the inherent flaws of the orthodox theories, critical theorists assert that theory is never politically neutral (Bellamy, Williams and Griffin 20I0: 27); rather it is "always for someone or for some 
purpose. All theories have a perspective" (Cox I98I: I28. Italics in original). Thus, critical theory seeks to, as its purpose clearly dictates, unveil the injustices associated with orthodox theories and examine 'structural transformation' as a way to achieve human emancipation (Horkheimer I982). With this goal (and also in relation to peacekeeping), critical theorists, according to Pugh (2004: 39) examine the contexts (global structure and international politics) within which peacekeeping operates and contends that peacekeeping interventions serve a very limited, problem-solving or managerial purpose that is, to sustain a particular world order politics under the auspices of liberal imperialism. Peacekeeping, argue critical theorists, is nothing but counter-insurgency operations resourced and bankrolled by rich and powerful states with the goal of achieving and furthering their political and military dominance and economic interests in particular geopolitical arenas.

Critical theorists contend that global capitalism has divided the world into the haves (rich) and haves nots (poor, peripheral regions) where the latter are characterised by political instability, economic decay and poverty with the end-result of state failure and eventual turmoil due to the rise of anarchy. Warlords subsequently fill the vacuum created by the collapse of official government structures in the world peripheral regions and competitions ensue between marauding warlords, through armed violence, in their quest to achieve and protect their economic objectives and interests respectively. Therefore, instability and state collapse subsequently gives way to the 'war economy' (Pugh, Cooper with Goodhand 2004: 3) that threatens global capitalist interests that depend on international trade and raw materials from the poor regions of the global economy for industrial purposes linked to wealth accumulation and thereby oiling of the international political economy. Therefore, disorder in the peripheral regions necessitated peacekeeping's deployment by the global centre, usually through proxies (such as the UN and regional organisations) to safeguard the capitalist international political economy. Therefore, and following the logic of critical theory, the need for and implementation of peace operations are, as Bellamy, Williams and Griffin (2010: 28) state, based on the arguments of Pugh's (2004) and Duffield's (200I) studies, necessary to protect the existing 'neoliberal economic order across the globe.' Critical theorists put an accent on the quest for emancipation knowledge and freedom from structures and processes of the global capitalist domination. They have argued that peace operations can result in human emancipation when the oppressed and marginalised categories in the society are recognised, their voices heard, and their plights and experiences are taken into consideration. By focussing on the plights of these groups, it is believed that the sources of their problems and how they cope with their terrible situations will be better understood by 
peacekeeping agencies which in the long run will give peacekeeping agencies and actors the opportunity to take these into consideration, especially in the process of negotiating peace agreements (Stamnes 2004: I64).

\section{Final Remarks}

After having discussed the four theoretical approaches to the study of peacekeeping we acknowledge that there is no single theory (or a metatheory) that fully explains the whole gamut of issues involved in peace operations. For, as Bellamy, Williams and Griffin (20I0: 29) have agreed, the above theoretical traditions provide different ways in which to comprehend peacekeeping. Taking cognisance of the fact that the choice of theoretical framework invariably determines what to study, how to study it and the ways in which these choices influence possible study outcomes, a single theory is highly unlikely to fully explain the complexities of contemporary peace operations, especially in a continent like Africa featuring different actors (the UN, the $\mathrm{AU}$ and such sub-regional organisations as ECOWAS). While this limitation is noted, we argue that peacekeeping is best understood through the application of (a combination of) many theories in order to uncover the motives of peacekeeping authourising institutions, peacekeepers as well as the role(s) peacekeeping missions play and the interest they serve. Despite this reality, many peacekeeping scholars and their researches, especially in Africa, often draw on the liberal peace theory because the post-Westphalian conception of peacekeeping within the liberal theoretical tradition, they believe, captures the reality of, for example, Africa's new peace and security management system (that is, the African Peace and Security Architecture or the APSA) where the principle of noninterference in internal conflicts was replaced by that of non-indifference (Aneme 2008a\&b; Bellamy 2009; Dersso 2010; Engel and Gomes 2009; Murithi 2008; 2009a\&b; Kioko 2003). Truly, the AU to some extent can be viewed as an institution committed to promoting democracy, good governance, human rights and the protection of African people (Zweifel 2006: I48). Under its predecessor, the Organisation of African Unity (OAU) regime, state-centrism and the norm of sovereignty prevented the organisation from deploying peace missions to deal with purely internal conflicts (Badmus 2008; Imobighe 1996) ${ }^{9}$. However, by legislating and creating the

9 The OAU's adherence to the purposes and principles of sovereignty, territorial integrity and non-interference hindered the viability of the organisation in intra-state conflicts in Africa. An exception to this was the civil war in Chad in the I980s. In Chad, it was not until France's intervention and Gaddaffi's Libya military support to one of the belligerents that the OAU started playing active role in the conflict. This is because the OAU saw the civil war as one with 
AU Constitutive Act on democratic values and the concepts of human security and the Responsibility to Protect (R2P) with Article $4(\mathrm{~h})$ of the constitutive framework, all of this gives the organisation the right to intervene in a member state in responding to grave circumstances. This legislation (The AU Constitute Act) has apparently laid a foundation to allow the deployment of African peacekeepers to restore order in a member state thereby enabling the AU to export democratic values into states that experience instability. The preference of and choice towards adopting liberal peace theory does not of necessity suggest that all its philosophical and logical positions are well embedded in African peacekeeping efforts. They are often not due to mis-governance and political crises in many countries of the continent. It is in this light that the normative frameworks of the APSA espouse liberal tenets and accordingly AU peacekeeping forces are mandated to restore order where chaos prevails in the form of armed conflicts and violence, especially where civilian populations are affected. Despite this benefit of liberal theoretical tradition, it cannot solely explain and capture the reality of Africa's new peace and security management system and the whole gamut of issues involve in complex, multidimensional peace operations/peace support operations in live-war zones of the world, as in Somalia.

\section{REFERENCES}

Adebajo, A. (2002) Building Peace in West Africa: Liberia, Sierra Leone and Guinea Bissau (Boulder, CO: Lynne Rienner for IPA).

Aneme, G. A. (2008a) “The African Standby Force: Major Issues under Mission Scenario Six'”, Political Perspectives, 2 (I).

Aneme, G. A. (2008b) A Study of the African Union's Right of Intervention Against Genocide, Crime Against Humanity and War Crimes (Oslo: Faculty of Law, University of Oslo).

Archibugi, D., and D. Held (eds) (I995) Cosmopolitan Democracy (Cambridge: Polity Press).

Badmus, I. A. (2008) "Africa: In Search of Security after the Cold War", International Journal of African Studies, II: 203-245.

Badmus, I. A., (2015) The African Union's Role in Peacekeeping: Building on Lessons Learned from Security Operations. Basingstoke and New York: Palgrave Macmillan.

external colouration. 
Badmus, I. A., (20I7), "Australia, New Zealand and Regional Security in the Pacific: Reflections on Peacekeeping in the Solomon Island and Papua New Guinea (Bougainville)", Austral: Brazilian Journal of Strategy and International Relations. 6(II): 9-36.

Barber Benjamin (I996) “The Constitutional Faith”, in Cohen Joshua (ed.), For Love of Country. Boston: Beacon Press.

Barnett, M. (I995) "The New United Nations Politics of Peace: From Juridical Sovereignty to Empirical Sovereignty", Global Governance I(I): 79-97.

Bassey, C. (I993) "Nigeria in ECOMOG: The Dilemma of Preventive Diplomacy?" in Jide Owoeye (eds), Nigeria in International Institutions. Ibadan: College Press.

Bellamy, A. J. (2004) “The 'Next Stage' in Peace Operations Theory,” International Peacekeeping II (I): I7-38.

Bellamy, A. J. (2009) Responsibility to Protect: The Global Effort to End Mass Atrocities (Cambridge: Polity Press).

Bellamy A. J., and P. Williams (2004) "Introduction: Thinking Anew about Peace Operations," International Peacekeeping II(I): I-I5.

Bellamy, A. J., P. Williams, and S. Griffin (2004) Understanding Peacekeeping (Cambridge: Polity Press).

Bellamy, A. J., and P. D. Williams and S. Griffin (2010) Understanding Peacekeeping. 2nd. edn (Cambridge: Polity Press).

Bello, M. L. (2003) “The Liberal Perspective of Globalisation: A Critique." Being the text of a paper presented at the conference on The Nigerian Society Under Democratic Rule, I999-2003. Department of Political Science, University of Ilorin, Nigeria.

Björkdahl, A. (2005) "Peace Operations and the Promotion of Cosmopolitanism", Statsvetenskaplig Tidskrift, IO7 (3): 2I5-234.

Boli, J., and G. M. Thomas (1997) "World Culture in the World Polity: A Century of International Non-Governmental Organisation", American Sociological Review, 92(2): I7I-90.

Booth, K. (20007) Theory of World Security (Cambridge: Cambridge University Press).

Boutros-Ghali, B. (I992) An Agenda for Peace (New York: UN Department of Public Information).

Boutros-Ghali, B. (I993) “UN Peacekeeping in New Era: A New Chance for Peace", World Today.

Chan, S. (I997) "In Search of Democratic Peace: Problems and Promise", 
Mershon International Studies Review, 4I: 59-9I.

Cheah Peng and Robbins Bruce (eds) (I998), Cosmopolitics. Minneapolis: University of Minnesota Press.

Chesterman, S. (2002) "East Timor in Transition: Self-Determination, State-Building and the United Nations", International Peacekeeping, 9(I).

Chopra, J. (2002) "Building State-failure in East Timor", Development and Change, 33(5): 970-1000.

Cox, R. (I98I) "Social Forces, States and World Orders: Beyond International Relations Theory" Millennium: Journal of International Studies, Io(2).

Dallaire, R. (2004) Shake Hands with the Devil: The Failure of Humanity in Rwanda.

Demurenko, A., and A. Nikitin (I997) "Basic Terminology and Concepts in International Peacekeeping Operations: An Analytic Review", Low Intensity Conflict and Law Enforcement, 6(I): III-I26.

Dersso, S. A. (2010) The Role and Place of the African Standby Force Within the African Peace and Security Architecture (ISS Paper 209. Pretoria: Institute for Security Studies).

Diehl, P. F. (2008) Peace Operations (Malden, MA: Polity Press).

Diehl, P. F., J. Reifschneider and P. Hensel (I996) "United Nations Intervention and Recurring Conflict", International Organisation, 40(4): 683700.

Diehl, P. F., D. Druckman, and J. Wall (I998) “International Peacekeeping and Conflict Resolution: A Taxonomic Analysis with Implications", International Peacekeeping, 42(I): 33-55.

Diehl, P. F., D. Druckman, (2010). Evaluating Peace Operations. Boulder, CO.: Lynne Rienner

Duffield, M. (200I). Global Governance and the New War (London: Zed Books).

Duke, S. (I994) “The State and Human Rights: Sovereignty versus Humanitarian Intervention”, International Relations, XII(2): 25-48.

Dunne, T. (20II) "Liberalism" in J. Baylis, S. Smith and P. Owens (eds). The Globalisation of World Politics: An Introduction to International Relations. 5th edn (Oxford: Oxford University Press), pp. IO०-II3.

Durch, W. J. (ed.) (1993) The Evolution of UN Peacekeeping: Case Studies and Comparative Analysis (New York: St. Martin's Press).

Durch, W. J. (ed.) (I997) "Keeping the Peace: Politics and Lessons of the I990s", in W. J. Durch (ed), UN Peacekeeping, American Policy, and the 
Uncivil Wars of the 1990 (London: Macmillan).

Engel, U., and P. Gomes (2009) “The African Union's New Peace and Security Architecture: Towards an Evolving Security Regime?", African Security, 2(2): 82-96.

Falk, R. (I998) “The United Nations and Cosmopolitan Democracy: Bad Dream, Utopian Fantasy, Political Project”, in D. Archibugi, D. Held and M. Köhler, (eds) Re-imagining Political Community. Studies in Cosmopolitan Democracy (Cambridge and Oxford: Polity Press), pp. 3093II

Fetherston, A. B. (I994a) Towards a Theory of United Nations Peacekeeping (New York: St. Martin's).

Fetherston, A. B. (I994b) "Putting the Peace Back into Peacekeeping: Theory Must Inform Practice", International Peacekeeping, I(I): 3-29.

Fetherston, A. B. (2000) "Peacekeeping, Conflict Resolution, and Peacebuilding: A Reconsideration of Theoretical Frameworks", in T. Woodhouse and O. Ramsbotham Oliver (eds), Peacekeeping and Conflict Resolution (London Frank Cass), pp. 190-218

Fetherston, A. B., O. Ramsbotham and T. Woodhouse (I994) "UNPROFOR: Some Observations from a Conflict Resolution Perspective", International Peacekeeping, I(2): 179-203.

Ginifer, J. (2002) "Eyewitness: Peacebuilding in the Congo: Mission Impossible?," International Peacekeeping, 9(3): I2I-I28.

Goldstone, A. (2004). "UNTAET with Hindsight: The Peculiarities of Politics in an Incomplete State". Global Governance: 10: 83-98.

Goulding, M. (1993) “The Evolution of United Nations Peacekeeping”, International Affairs, 69(3): 45I-464.

Hannerz, U. (2005) “Cosmopolitanism”, in J. Vincent and D. Nugent (eds), Companion to the Anthropology of Politics (Oxford: Blackwell), pp. 6985 .

Held, D. (I995) Democracy and the Global Order (Cambridge: Polity).

Himmelfarb, G. (I996) “The Illusions of Cosmopolitanism”, in J. Cohen (ed) For Love of Country (Boston: Beacon Press), pp. $\mathrm{xx}$

Hoffmann, S. (I995) “The Crisis of Liberal Internationalism”, Foreign Policy, 98: 159-I77

Horkheimer, M. (I982) Critical Theory (New York: Seabury Press).

Holmberg, B. (I998) Passing the Open Windows: A Quantitative and Qualitative Approach to Immediate Military Balance and Escalation of Protracted 
Conflicts (Uppsala: Department of Peace Research, Uppsala University), Report No. 47.

Howard L. M. (2002) "UN Peace Implementation in Namibia: The Causes of Success," International Peacekeeping 9(I): 99-I32.

Ian, M., A. Mayer-Rieckh (2005). "The United Nations and East Timor: From Self-Determination to State-Building." International Peacekeeping I2 (I): I25-I45.

Ignatieff, M. (2002) "Intervention and State Failure" in N. Mills and K. Brunner (eds), The New Killing Field: Massacre and the Politics of Intervention (New York: Basic Books).

Imobighe, T. A. (I996) "The Analysis of Political Issues Raised by OAU Peacekeeping in Chad", in M. A. Vogt and L. S. Aminu (eds), Peacekeeping as a Security Strategy in Africa: Chad and Liberia as Case Studies. Volume I (Enugu: Fourth Dimension Publishing Co. Ltd.), pp. 24I-259.

Jabri, V. (2010) War, Government, Politics: A Critical Response to the Hegemony of the Liberal Peace, in O. P. Richmond (ed.), Palgrave Advances in Peacebuilding: Critical Developments and Approaches (Hampshire: Palgrave Macmillan), pp. 4I-57.

James, A. (I990) Peacekeeping in International Politics (London: Macmillan Press).

James, A. (1996) Britain and the Congo Crisis, 1960-63 (London: Macmillan).

Johnstone, I. (2005) "Peace Operations Literature Review." Retrieved from http://www.peacekeepingbestpractices.unlb.org/pbps/library/ Peace\%2ooperations\%2ofinal\%2oliterature\%2oreview.pdf cessed, 4 January 2012).

Kaldor, M. (I999) New and Old Wars: Organised Violence in a Global Era (Cambridge: Polity).

Kaldor, M. (2003) “American Power: From 'Compellance' to Cosmopolitanism?” International Affairs, 79(I): I-22.

Kaldor, M. (2006) New and Old Wars. 2nd edn. (Cambridge: Polity).

Keohane, O. R. (I986) “Theory of World Politics: Structural Realism and Beyond", in R. O. Keohane (ed). Neorealism and its Critics (New York: Columbia University Press), pp. I58-203.

Kioko, B. (2003) “The Right of Intervention Under the African Union's Constitutive Act: From Non-interference to Non-intervention", International Review of the Red Cross, 852: 807-825.

Kondoch, B. (2007) International Peacekeeping (Hampshire: Ashgate). 
Mackinlay, J., and J. Chopra (I992) “Second Generation Multinational Operations." Washington Quarterly, I5: II3-I34.

McNeely, L. Connie (I995) Constructing the Nation-State: International Organisation and Prescriptive Action (Westport, CT: Greenwood).

Mearheimer, J. J. (I994) “The False Promise of International Institutions", International Security, I9(3): 5-49.

Morgenthau, H. J. (1973) Politics Among Nations: The Struggles for Power and Peace (New York: Alfred, A. Knopf).

Murithi, T. (2008) “The African Union's Evolving Role in Peace Operations: The African Union Mission in Burundi, the African Union Mission in Sudan and the African Union Mission in Somalia”, African Security Review, I7(I): 70-82.

Murithi, T. (2009a) “The African Union's Foray into Peacekeeping: Lessons for the Hybrid Mission in Darfur", Journal of Peace, Conflict and Development, I4.

Murithi, T. (2009b) “The African Union's Transition from Non-Interference to Non-Indifference: An Ad Hoc Approach to the Responsibility to Protect?" Internationale Politik und Gesellschaft, r: 90-1o6.

Neethling, T. (2009) "Whither Peacekeeping in Africa: Revisiting the Evolving Role of the United Nations", African Security Review, I8(I): 2-20.

Nishihara, M. (I993) “Trilateral Country Roles: Challenges and Opportunities", in Keeping the Peace in the Post-Cold War Era: Strengthening Multilateral Peacekeeping (New York: Trilateral Commission), pp. 5I-59.

Nussbaum, M. (1996) "Patriotism and Cosmopolitanism", in J. Cohen (ed.) For Love of Country (Boston: Beacon Press), pp. xx.

Olonisakin, 'F. (2008) Peacekeeping in Sierra Leone: The Story of UNAMSIL (Boulder, CO: Lynne Rienner).

O'Neill, J. T., and N. Rees (2005) United Nations Peacekeeping in the Post-Cold War Era (London and New York: Routledge).

Owen, J. M. (I994) “How Liberalism Produces Democratic Peace” International Security, I9(2): 87-I25.

Paris, R. (2000) "Broadening the Study of Peace Operations", International Studies Review, 2(3): 27-44.

Paris, R. (2002) "International Peacebuilding and the 'Mission Civilisatrice' ", Review of International Studies, 28(4): 637-656.

Paris, R. (2003) Peacekeeping and the Constraints of Global Culture. European Journal of International Relations, 9(3): 44I-473. 
Paris, R. (2004) At War's End: Building Peace after Civil Conflict (New York: Cambridge University Press).

Pugh, M. (200I) “The Challenge of Civil-Military Relations in International Peace Operations", Disasters, 25(4): 345-357.

Pugh, M. (2003) "Peacekeeping and International Relations Theory: Phantom of the Opera?" International Peacekeeping, Io(4): IO4-II2.

Pugh, M. (2004) "Peacekeeping and Critical Theory," International Peacekeeping, II(I): 39-58.

Pugh, M., and N. Cooper with J. Goodhand (2004) "War Economies in a Regional Context: Challenges of Transformation" (Boulder, CO.: Lynne Rienner).

Ratner, S. (I995) The UN Peacekeeping: Building Peace in Lands of Conflict after the Cold War (New York: St. Martin's).

Richmond, O. P., and J. Franks (20II) Liberal Peace Transitions: Between Statebuilding and Peacebuilding (Edinburg: Edinburg University Press).

Richmond, O. P. (2007) The Transformation of Peace (New York: Palgrave Macmillan).

Richmond, O. P. (20I0) A Genealogy of Peace and Conflict Theory in O. P. Richmond (ed.), Palgrave Advances in Peacebuilding: Critical Developments and Approaches (Hampshire: Palgrave Macmillan), pp. I4-40.

Rikhye, I. J. (1984) The Theory and Practice of Peacekeeping (London: Hurst).

Rogie, E. (2003) MONUC and the Challenges of Peace Implementation in the Democratic Republic of Congo. Tswhane: ISS Report.

Russet, B. and S. Harvey (2000) "From Democratic Peace to Katian Peace: Democracy and Conflict in the International System", in M. Midlarsky (ed.), Handbook of War Studies. 2nd edn (Ann Arbor: University of Michigan Press).

Ryan, S. (2000) “United Nations Peacekeeping: A Matter of Principles?” in O. Ramsbotham and T. Woodhouse (eds), Peacekeeping and Conflict Resolution (Portland, OR: Frank Cass), pp. 27-47.

Segal, D. (I995) "Five Phases of United Nations Peacekeeping: An Evolutionary Typology", Journal of Politics and Military Sociology, 22(2): 65-79.

Skiemann Robert, (1998), National Contingents in the United Nations Peacekeeping Forces. (Dordrecht: Martinus Nijohoff Publishers).

Skogmo, B. (I989) UNIFIL: International Peacekeeping in Lebanon, 1978-1988 (Boulder, CO.: Lynne Rienner). 
Stamnes, E. (2004) Critical Security Studies and the United Nations Preventive Deployment in Macedonia. International Peacekeeping II(I): I6II8I.

Straus, S., (20I2) "Wars Do End! Changing Patterns of Political Violence in Sub-Saharan Africa." African Affairs, III/443, pp. I79-20I.

Suhrke A. (200I) Peacekeepers as Nation-builders: Dilemmas of the UN in East Timor. International Peacekeeping 8(4): I-20.

Taylor, P. (I999) "The United Nations in the I990s: Proactive Cosmopolitanism and the Issue of Sovereignty", Political Studies, XLVII: 538-565.

Thakur, R., and A. Schnable (eds) (200I) United Nations Peacekeeping Operations: Ad Hoc Missions, Permanent Engagement (Tokyo: United Nations University Press).

Thakur, R. (2005) "From Peacekeeping to Peace Operations", Conflict Trends, 4: 3-9.

Thomas, G. M., J. W. Meyer, F. O. Ramirez and J. Boli (I987) Institutional Structure: Constituting State, Society, and the Individual (London: Sage).

Vasquez, A. J. (1983) The Power of Power Politics: A Critique (Frances Printer).

Waltz, K. N. (I979) Theory of International Politics (Readings: Addison-Wesley Publishing Company).

Wayman F., and P. F. Diehl (ed.) (I994) Reconstructing Realpolitics (Ann Arbor: The University of Michigan Press)

Weiss G. T. (I995) "On the Brink of a New Era? Humanitarian Interventions, 9I-94", in D. Donald and B. Hayes (eds), Beyond Traditional Peacekeeping (London: Macmillan).

United Nations (I990) The Blue Helmets: A Review of the United Nations Peacekeeping. 2nd edn. New York: United Nations.

Weiss G. T., et al. (1997) The United Nations and Changing World Politics. Boulder: Westview.

White, N. D. (1997) Keeping the Peace: The United Nations and the Maintenance of International Peace and Security (Manchester: Manchester University Press).

Wolfgang, B., and M. Vadset (eds) (1998) United Nations Peacekeeping in Trouble: Lessons Learned from the Former Yugoslavia (Aldershot: Ashgate).

Wyn Jones, R. (I999) Security, Strategy and Critical Theory (Boulder, CO.: Lynne Rienner).

Zolo, D. (I997) Cosmopolis: Prospects for World Government (Oxford: Polity).

Zweifel, T. D. (2006) International Organisations and Democracy: Accountabili- 
ty, Politics and Power (Boulder, CO.: Lynne Rienner).

\begin{abstract}
This paper reviewed some extense literature in peacekeeping. The review of the literature focused on two areas - concepts and theories of peacekeeping. After having discussed the three major approaches to think conceptually about peacekeeping in the literature, we argued that despite the existence of these multiple frameworks for addressing the conceptual problems of peacekeeping, they overlooked the imperative of the structures and processes of world politics, their impacts and how these have conditioned the roles of peacekeepers in it. Then, we examined four of the main theoretical approaches that are discernible in the peacekeeping literature, which offer possible frameworks for the analysis and interpretation of peacekeeping research. We argued that there is no single theory (or a metatheory) that fully explains the whole gamut of issues involved in peace operations. This is because these theoretical traditions provide different ways in which to comprehend peacekeeping. A single theory is highly unlikely to fully explain the complexities of contemporary peace operations, especially in a continent like Africa featuring different peacekeeping actors. Therefore, peacekeeping is best understood through the application of many theories in order to uncover the motives of peacekeeping authourising institutions, peacekeepers as well as the role(s) peacekeeping missions play and the interest they serve.
\end{abstract}

\title{
KEYWORDS
}

Peacekeeping; Peace Operations; Peace Enforcement, Peacebuilding; United Nations; Regional Organisations. 